\title{
REDD+ as a Source of Conflict and Cooperation (Perspective)
}

\author{
David Gritten*, Chandra Silori*, Regan Suzuki* and Abmad Dhiaulhaq* \\ "RECOFTC - The Center for People and Forests, Thailand \\ Corresponding author: david.gritten@recoftc.org
}

\section{INTRODUCTION}

Throughout the developing world, any action, or proposed action, that affects the way forests are managed will inevitably be contentious (de Koning et al. 2007; Gritten et al. 2012). The importance of this is underlined when considering the number of forest-dependent people in the world; for example, in Asia there are up to 450 million people living in and around forests in the region (ADB 2003). In this context, the development and implementation of Reducing Emissions from Deforestation and Forest Degradation (REDD+), with its ambitious scope and implications on environmental, social and economic levels, is being scrutinized and discussed by many interest groups, and is seen by many of these groups as being a possible source of conflict (Yasmi $e t$ al. 2012).

The development of REDD+ reflects the belief that forests could play a fundamental role in climate change mitigation, with 12-17 percent of global greenhouse gas emissions being attributed to land-use changes and loss of forests (IPCC 2007). As the name suggests, REDD+ sets out to reduce these emissions, with the ' + ' emphasizing sustainable forest management, as well as the role of conservation and enhancement of forest carbon stocks. One could argue that the ' + ' and how it is interpreted is the bone of contention for many, including civil society organizations (CSOs), forest communities, as well as those taking part in negotiations on REDD+ at the international level.

As with any activity affecting the management of forest resources, sustainability is the key. REDD+ draws on different interpretations, and with that emphasis, on what is required for management of a forest to be sustainable. REDD+ is a classic case of an external, in this case international process affecting how forests are managed at national and sub-national levels. Simply put, each of these levels-the international (e.g. reducing emissions), national (e.g. economic development and poverty reduction) and sub-national (e.g. safeguarding way of life) - has its own priorities for how forests are managed and this is where the seeds of conflict are sown. The seeds then grow and are fed by issues such as weak rights and nonparticipatory methods in decision making. For REDD+ to succeed at the various levels, it must be both effective and equitable, dealing with the various interests and values at play in a coherent manner.

In the above context, the aim of this paper is to briefly examine possible areas of conflict within REDD+ and put forward recommendations aiming at minimizing the negative aspects of conflict and, in turn, maximizing the positives.

\section{REDD+ AS A DRIVER OF CONFLICT}

The implementation of the REDD+ initiative comes with significant risks, with great potential for exacerbating ongoing conflicts, or creating new ones. Naturally, the way in which these risks are managed is fundamental to the success of the initiative; therefore, tools for supporting REDD+ proponents, grassroots organizations, are fundamental.

RECOFTC - The Center for People and Forests, driven by its vision of local communities being actively involved in the equitable and 
ecologically sustainable management of forest landscapes, has been examining the fundamentals of REDD+ and how it is being developed and implemented across the region. As part of this work, the organization is developing a framework identifying possible sources of conflict, i.e. sources of impairment felt by communities resulting from forest management, including REDD+, with the implementation of REDD+ (Patel et al. 2013, Table 1). To date, the framework has been applied in Nepal and Vietnam and is currently being applied in REDD+ sites in Cambodia and Myanmar

\section{Table 1. Sources of impairment}

\begin{tabular}{|c|c|c|}
\hline Source & Examples of impairment & Justification \\
\hline $\begin{array}{l}\text { Access and use } \\
\text { restriction }\end{array}$ & $\begin{array}{l}\text { Regulations limiting } \\
\text { stakeholders' access to, or use } \\
\text { of, forests due to creation of } \\
\text { protected areas and/or granting } \\
\text { of land concessions to private } \\
\text { companies }\end{array}$ & $\begin{array}{l}\text { Access to natural resources is essential in } \\
\text { meeting the subsistence needs of forest- } \\
\text { dependent stakeholders. Policies or } \\
\text { practices that limit local access and } \\
\text { ability to harvest forest products can } \\
\text { cause conflict. REDD + may come with } \\
\text { such restrictions that have potential to } \\
\text { alter the relationship that people have } \\
\text { with forests. }\end{array}$ \\
\hline $\begin{array}{l}\text { Benefit } \\
\text { distribution }\end{array}$ & $\begin{array}{l}\text { Unclear or inequitable } \\
\text { arrangements for distributing } \\
\text { benefits from forest } \\
\text { management }\end{array}$ & $\begin{array}{l}\text { The lack of fair and equitable benefit } \\
\text { distribution mechanisms may create } \\
\text { hostility among local stakeholders } \\
\text { regarding their share of expected benefits. } \\
\text { The potential benefits from REDD+ } \\
\text { must be factored into this already } \\
\text { complex equation of benefit generation } \\
\text { and distribution. }\end{array}$ \\
\hline $\begin{array}{l}\text { Competing } \\
\text { demands }\end{array}$ & $\begin{array}{l}\text { Overlap between extractive } \\
\text { management objectives, } \\
\text { development agenda, } \\
\text { prioritizing economic growth, } \\
\text { opportunity costs of } \\
\text { conservation and cultural } \\
\text { importance of forest areas }\end{array}$ & $\begin{array}{l}\text { Prioritization of conservation or } \\
\text { exploitation for economic development } \\
\text { makes natural resource management } \\
\text { highly contentious. Cultural values } \\
\text { attached to the resources (e.g. sacred } \\
\text { forests, ancestral land) place further } \\
\text { demands that can influence resource } \\
\text { management. Alternative forest } \\
\text { management options might generate } \\
\text { more income, making REDD + a less } \\
\text { favourable option to the communities. }\end{array}$ \\
\hline $\begin{array}{l}\text { Conflict } \\
\text { management } \\
\text { capacity }\end{array}$ & $\begin{array}{l}\text { Lack of support or resources } \\
\text { from local or central } \\
\text { government for managing } \\
\text { conflict }\end{array}$ & $\begin{array}{l}\text { The lack of a clear and effective } \\
\text { mechanism or process for managing } \\
\text { conflict over forest land and resources } \\
\text { may escalate conflict. Ongoing tensions } \\
\text { can undermine existing institutions, } \\
\text { increase the socioeconomic vulnerability } \\
\text { of dependent users, and result in } \\
\text { environmental degradation. The absence }\end{array}$ \\
\hline
\end{tabular}




\begin{tabular}{|c|c|c|}
\hline & & $\begin{array}{l}\text { of grievance mechanisms or unclear } \\
\text { processes aimed at ensuring social } \\
\text { safeguards, like Free, Prior and } \\
\text { Informed Consent (FPIC), could } \\
\text { make REDD + itself a driver for } \\
\text { conflict. }\end{array}$ \\
\hline Leadership & $\begin{array}{l}\text { Leadership is not representative, } \\
\text { accountable, or transparent; elite } \\
\text { groups dominate decision-making } \\
\text { processes and bodies }\end{array}$ & $\begin{array}{l}\text { Community elite often exert } \\
\text { disproportionate influence on } \\
\text { executive committees and other } \\
\text { leadership positions. Their elevated } \\
\text { social status enables them to } \\
\text { circumvent accountability or } \\
\text { transparency and misuse their } \\
\text { leadership roles to engage in corrupt } \\
\text { practices. The approach to and } \\
\text { content of REDD+ implementation } \\
\text { may strengthen these prevalent } \\
\text { power imbalances. }\end{array}$ \\
\hline $\begin{array}{l}\text { Legal and } \\
\text { policy } \\
\text { frameworks }\end{array}$ & $\begin{array}{l}\text { Dominance of state law over local } \\
\text { and/or customary traditions; } \\
\text { multiple and ambiguous } \\
\text { regulations for forest management; } \\
\text { legislation not well understood or } \\
\text { effectively enforced }\end{array}$ & $\begin{array}{l}\text { Effective forest management depends } \\
\text { on the clarity and consistency of } \\
\text { legal and policy frameworks. State } \\
\text { regulations often do not explicitly } \\
\text { accommodate customary laws or } \\
\text { reflect local realities. The resulting } \\
\text { legal pluralism can create conflict. } \\
\text { Inadequate provisions for } \\
\text { implementation, monitoring and } \\
\text { evaluation of programmes likewise } \\
\text { contribute to legal instability. The } \\
\text { commoditization of carbon through } \\
\text { REDD+ will add complexity to } \\
\text { existing regulatory frameworks for } \\
\text { forest management. }\end{array}$ \\
\hline $\begin{array}{l}\text { Participation } \\
\text { and information }\end{array}$ & $\begin{array}{l}\text { Lack of understanding and access } \\
\text { to information; limited } \\
\text { opportunities for stakeholders to } \\
\text { meaningfully participate in forest } \\
\text { management }\end{array}$ & $\begin{array}{l}\text { State forest policies and interventions } \\
\text { are sometimes made without active } \\
\text { participation of local stakeholders, } \\
\text { and thereby fail to account for local } \\
\text { rights and practices. Inadequate } \\
\text { consultation and communication } \\
\text { with stakeholder groups can lead to } \\
\text { conflict. Even where REDD+ } \\
\text { implementation is equipped with } \\
\text { grievance mechanisms and processes } \\
\text { to ensure that affected parties } \\
\text { understand and agree with the } \\
\text { implications, the use of such tools is } \\
\text { not fullproof. }\end{array}$ \\
\hline
\end{tabular}




\begin{tabular}{|c|c|c|}
\hline $\begin{array}{l}\text { Quality of } \\
\text { resources }\end{array}$ & $\begin{array}{l}\text { Actual and perceived decrease in } \\
\text { the condition of forest resources } \\
\text { caused by an external actor }\end{array}$ & $\begin{array}{l}\text { Decreases in the amount or quality of } \\
\text { available forest land and resources can } \\
\text { create tensions among stakeholders. } \\
\text { The pursuit of REDD + benefits may } \\
\text { lead to intentionally skewed } \\
\text { perceptions of forest quality. }\end{array}$ \\
\hline $\begin{array}{l}\text { Tenure } \\
\text { security }\end{array}$ & $\begin{array}{l}\text { Overlapping boundaries between } \\
\text { state and community forests, } \\
\text { contested boundaries, lack of } \\
\text { recognition of customary rights } \\
\text { and traditional uses of the land }\end{array}$ & $\begin{array}{l}\text { The lack of clear and consistent } \\
\text { recognition of stakeholders' claims to } \\
\text { forestland and resources can fuel } \\
\text { conflict. Such recognition could afford } \\
\text { stakeholders rights to manage, control } \\
\text { and utilize resources. In practice, } \\
\text { however, tenure arrangements are } \\
\text { vaguely defined or absent, leading to } \\
\text { overlapping boundaries between state } \\
\text { and community forests. This is } \\
\text { especially true where customary and } \\
\text { traditional rights are concerned. } \\
\text { REDD+ poses important questions } \\
\text { about carbon ownership and } \\
\text { entitlement to its benefits. }\end{array}$ \\
\hline
\end{tabular}

Source: Patel et al. 2013

In Nepal, the framework was applied in three watersheds-Kayarkhola (Chitwan District), Ludhikola (Gorkha District) and Charnawati (Dolakha District) - where REDD+ was piloted by the International Centre for Integrated Mountain Development (ICIMOD), Federation of Community Forestry Users, Nepal (FECOFUN) and Asia Network for Sustainable Agriculture and Bio-resources (ANSAB), with the financial support from the Norwegian Agency for Development Cooperation (NORAD). The findings suggested that some issues that could be a driver of conflict within Community Forest User Groups (CFUGs) were not adequately addressed by the REDD+ proponents, and national and local authorities. The representatives of communities that took part in the research particularly emphasized issues relating to benefit sharing, participation and provision for information sharing that were drivers of conflict prior to REDD+. For example, on the issue of benefit sharing, including the practical challenge of identifying poor households, the methods and results it was felt were prone to manipulation. Additionally, there was the concern of overemphasis on forest protection over harvesting (for more information see Patel et al. 2013).

The framework can be used as a basis to help predict conflicts not only related to REDD+ (e.g. to ensure that lessons are learned from the 'readiness' phase of REDD+ prior to actual implementation phases) but also in other areas of community-outsider relations regarding forest management and within this conflict management. Conflict management in this context is not just for resolving a conflict, but for addressing the underlying causes of conflict that may jeopardise the implementation of REDD + as well as maximise positive impacts of any conflict when it does occur, i.e. conflict transformation.

\section{REDD+ AS A DRIVER OF SOCIAL TRANSFORMATION}

REDD + can also provide impetus for addressing the underlying drivers of conflict, i.e. sources of impairment such as tenure. The potential of 
REDD + in this role has been recognized by various bodies, as illustrated by the active participation of many CSOs such as the Indigenous People's Alliance (AMAN)in REDD+ Indonesia, based on the expectation that it will facilitate the opportunity to strengthen indigenous peoples' land rights (Pye 2012). Additionally, under the United Nations Framework Convention on Climate Change (UNFCCC), Cancun Agreement (CoP 16) and Durban Outcomes (CoP 17), safeguards are set out that implicitly seek to ensure that REDD+ is not a driver of conflict. For example, the safeguards in the Cancun Agreement include 'the full and effective participation of relevant stakeholders, in particular indigenous peoples and local communities. These safeguards place pressure on relevant government institutions and REDD+ proponents, as well as decision-making bodies, for example, within CFUGs, to address the issues of equity to enable them to access the REDD+ funds. An example is the Norway-Indonesia Partnership, where Norway will provide up to US\$ 1 billion over the coming years, provided that Indonesia delivers not only on deforestation and forest degradation, but does so in a participatory and transparent manner (Wertz-Kanounnikoff and McNeill 2012) addressing many of the sources of impairment presented in Table 1. The REDD + initiative's movement on this will encourage governments to address issues relating to governance, if they wish to have access to the large sources of funds that have been discussed.

The importance placed in addressing the threats to REDD+ as well as the opportunities it may provide at the social level, are demonstrated by the investment by numerous development organizations and donors such as NORAD and the Swiss Agency for Development and Cooperation (SDC). The funding and support has been translated into different projects at the grassroots level, e.g. the RECOFTC coordinated Grassroots Capacity Building for REDD+, and national and regional levels, e.g. ASEAN-Swiss Partnership on Social Forestry and Climate Change (ASFCC). The work of the former, for example, in advocating the use of Free, Prior and Informed Consent (FPIC) in REDD+ sites, as well as building the capacity of numerous stakeholders at the grassroots level, e.g. in Indonesia, Lao PDR, Myanmar, Nepal and Vietnam, helps to ensure that as REDD+ develops, they are able to actively contribute to the decisions on the implementation, as well as ensuring that they get appropriate benefits for their investments in their forests.

The increased awareness of the importance of participation regarding the sustainability of operations has driven governments and companies to increasingly involve key stakeholders in decision-making processes, such as social impact assessments and FPIC. There are, however, different drivers for this increased participation, as well as differing methods employed and impacts around the world (Gritten 2009; Gritten et al. 2009). Nevertheless, the development and implementation of REDD+ can be a catalyst for this positive development with the framework for REDD+, including funds coming from developed nations, requires that a great deal of emphasis is placed on addressing underlying causes of conflict that may arise through the implementation of REDD+, more so than if a different type of outsider intervention was to occur (i.e. pulp and paper company wishing to establish plantations). In other words REDD+, along with other international initiatives such as European Union Forest Law Enforcement Governance and Trade (EU FLEGT), can encourage governments to address issues that are sources of impairment (Table 1), thereby facilitating social transformation.

\section{CONCLUSION AND RECOMMENDATIONS}

Weak governance lies at the heart of the challenges facing forest management in Asia. 
REDD+ is a challenge, but also opportunity in terms of how it is designed and implemented, addressing issues related to, for example tenure security, benefit-sharing and how conflict is managed or transformed.

What do we want REDD+ to be? We want it to be a tool for encouraging sustainable management of forests in the holistic sense, not a tool for the management of carbon alone. REDD+ has significant potential to deliver on the former, as illustrated by the level of funding being discussed that are greater than all current investments in forest conservation (Phelps et al. 2010). The potential, however, will not be fulfilled until REDD+ proponents, national governments, REDD+ funders and international organizations, e.g. UN-REDD, as well as CSOs, including grassroots organizations, work together in ensuring that safeguards are in place. These safeguards would address the underlying causes of conflict (Table 1).

\section{SPECIFIC RECOMMENDATIONS}

1. Build the capacity of grassroots organizations, sub-national and national governmental organizations, as well as private organisations to coherently address the underlying causes of conflict that are likely to exacerbate with the implementation of REDD+. The inclusion of private sector emphasises the fact that, in most cases, the drivers of deforestation lie outside the forestland and in many other cases, for example, forestland concessions, trigger the conflict.

2. Research needs to be facilitated in the countries concerned. This paper is, to a large extent, based on limited application of REDD+. But once REDD+ starts to further roll out on the ground, additional issues are likely to arise. Therefore, diversifying research to different cultural and biophysical contexts and type and value of forests is another aspect that needs to be considered for further research. As part of this, the research should have the starting point that REDD+ could be a driver for conflict transformation. Additionally, a great deal can be learned from existing conflicts and how they are transformed that can help inform the potential conflict in REDD+.

3. From the REDD+ grassroots project point of view, there is a need to develop tools and methods to resolve or transform conflicts at the local level-identifying local cultural practices and making use of them to communicate the message of transforming conflict.

4. All articles on REDD+ have the same recommendation; address statutory and customary claims on forestlands and this opinion paper is no different. Secure tenure lies at the heart of sustainable management of forest (returning to the ' + ' in REDD+) as well as at the heart of safeguarding the basic human rights of the communities concerned. In other words, tenure for forest communities needs to be coherently and progressively addressed.

5. The next step beyond tenure is that, to further ensure the sustainable management of forests, communities need to be able to legally make a living from these forests, i.e. an enabling regulatory environment needs to exist whereby communities are able to harvest and sell timber. Governments in the region need to revisit the regulations regarding forest management and examine whether the regulations are providing the best route to the sustainable management of forest, including combating illegal logging.

\section{ACKNOWLEDGEMENTS}

The work is funded by RECOFTC-The Center for People and Forests, REDD-Net and NORAD funded regional project on Grassroots Capacity Building for REDD+. Additionally, we 
are grateful to International Center for Integrated Mountain Development (ICIMOD), Federation of Community Forestry Users, Nepal (FECOFUN), Asia Network for Sustainable Agriculture and Bio-resources (ANSAB) and the Norwegian Agency for Development Cooperation (NORAD) for their support in conducting the fieldwork in Nepal.

\section{REFERENCES}

ADB. 2003. Forest Policy. Working Paper June 2003. Manila Philippines: The Asian Development Bank

De Koning, R., Capistrano, D. and Yasmi, Y. 2007. The Role of Forest Tenure and Governance in Addressing the Global Challenge of Reducing Violent Conflict in Forest Countries. Center for International Forestry Research and Rights and Resources Initiative

Gritten, D. 2009. Facilitating Resolution of Forest Conflicts through Understanding the Complexity of the Relationship between Forest Industry and Environmental Groups. Dissertationes Forestales 91. Helsinki, Finland: The Finnish Society of Forest Sciences

Gritten, D., Mola-Yudego, B., Delgado-Matas, C. and Kortelainen, J. 2012. A Quantitative Review of the Representation of Forest Conflicts across the World: Resource Periphery and Emerging Patterns. Forest Policy and Economics (In press) doi:10.1016/ j.forpol.2012.06.008

Gritten, D., Saastamoinen, O. and Sajama, S. 2009. Ethical Analysis: A Structured Approach to Facilitate the Resolution of Forest Conflicts. Forest Policy and Economics, 11(8): 555560

IPCC. 2007. Climate Change 2007: The Physical Science Basis. Contribution of Working Group I to the Fourth Assessment Report of the Intergovernmental Panel on Climate Change. In: S. Solomon, D. Qin, M. Manning, Z. Chen, M. Marquis, K.B., Averyt, M. Tignor and H.L. Miller, (Eds.). NY, USA: Cambridge University Press

Patel, T., Dhiaulhaq, A., Gritten, D., Yasmi, Y., De Bruyn, T., Paudel, N.S., Luintel, H., Khatri, D.B., Silori, C. and Suzuki, R. 2013. Predicting Future Conflict under REDD+ Implementation. Forests, 4(2): 343-363.

Phelps, J., Webb, E.L., and Agrawal, A. 2010. Does REDD+ Threaten to Recentralize Forest Governance? Science, 328 312-313.

Pye, O. 2012. Carbon Markets and REDD in South-East Asia: An Interview with Chris Lang from REDD-Monitor. ASEAS-Austrian Journal of South-East Asian Studies, 5(2): 352-358.

Wertz-Kanounnikoff, S. and McNeill, D. 2012. Performance Indicators and REDD+ Implementation. In: Angelsen, A., M. Brockhaus, W. Sunderlinand L. Verchot, L. (Eds.) Analysing REDD+: Challenges and Choices, 233-46. CIFOR, Bogor, Indonesia.

Yasmi, Y., Kelley, L., Murdiyarso, D. and Patel, T. 2012. The Struggle over Asia's Forests: An Overview of Forest Conflict and Potential Implications for REDD+. International Forestry Review, 14: 1-11. 